
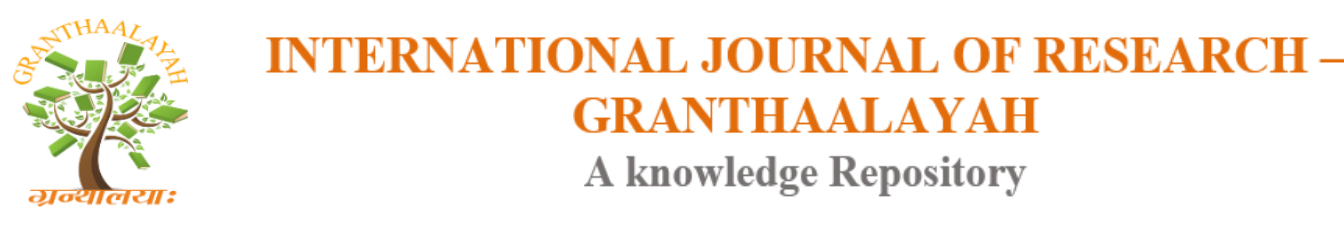

Social

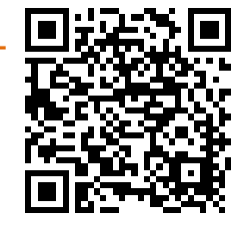

\title{
STRESSORS, EFFECTS AND COPING STRATEGIES AMONG TEACHERS IN SECONDARY SCHOOLS IN EDO STATE, NIGERIA
}

\author{
Osagie, Constance Iyore, Ph.D *1 \\ ${ }^{* 1}$ Department of Educational Foundations and Management, College of Education, Ekiadolor, \\ Benin
}

\begin{abstract}
The study examined stressors, effects and coping strategies among teachers in secondary schools in Esan Central Senatorial District, Edo State, Nigeria. The descriptive survey design was adopted for the study. The proportionate random sampling technique was used to select a total of three hundred and eight (308) teachers representing 50\% of the teachers from the entire population of all the six hundred and sixteen (616) public senior secondary school teachers in Esan Central Senatorial Edo State. The research instrument used was a 30-item questionnaire developed by the researcher and titled Stress Assessment Questionnaire (SAQ) for teachers. The content validity of this instrument was ensured by experts in Measurement and Evaluation, Ambrose Alli University Ekpoma. The test-retest method was used to determine the reliability of the instrument. Descriptive statistics such as mean (X) and standard deviation (S.D) was used to analyze the data collected. The result showed that stress is a cankerworm that emanates from work overload, crowded class conditions, poor working conditions, lack of social support and lack of teaching accessories among others. Based on findings, was concluded that stress lessens teachers' quality of instructional delivery, lowers teachers' morale, job satisfaction, job performance and increases attrition among teachers. Hence, it was recommended that teachers in Edo State should always endeavour to manage stress by getting emotional support from others such as more experience teachers who could give them directives on how to manage the current challenges they are facing at school.
\end{abstract}

Keywords: Stressors; Stress; Stress Coping Strategies.

Cite This Article: Osagie, Constance Iyore. (2018). "STRESSORS, EFFECTS AND COPING STRATEGIES AMONG TEACHERS IN SECONDARY SCHOOLS IN EDO STATE, NIGERIA." International Journal of Research - Granthaalayah, 6(9), 137-147. https://doi.org/10.5281/zenodo.1436784.

\section{Introduction}

Teachers are assets of inestimable value in the teaching of members of a given society. They play important roles in nation building by sharpening and molding learner's character. In the performance of this, teachers just like any other worker, face workplace stress that makes them fatigued, experience burn out, less effective on their duties. Stress among secondary school 
teachers comes from various aspects of life including developmental and social changes, financial and accommodation problems, work demands, and the specific demands of academia.

Busari (2011) submitted that stress can be the result of a number of situations at school. He categorized some workplace stressors as: (1) stress unique to the job such as workload, meaningfulness of work, hours of work, physical environment, isolation at the workplace (2) role in school such as role conflict, role ambiguity, responsibility for staff, conflicts occurring due to ill-defined school boundaries (3) Career development such as: over promotion, under promotion, lack of job security, thwarted ambitions 4) relationship at work such as poor relations with principals, subordinates, or colleagues, difficulties in delegation, threat of violence, harassment (5) school structure and climate such as participation or non-participation in decision making, management style and communication patterns among staff and member of the school community. According to Wainwright and Calnan (2002), stress contributes to heart diseases, hypertension, high blood pressure, and impairs the immune system among teacher. Stress is also linked to diabetes, muscle and joint pain, miscarriage during pregnancy, and allergies. Whatever causes the workplace stress epidemic, it has been established that it is one of the key problems of modern working life. Consequently, teachers who find it difficult to cope with the behaviour of students, take various measures to disregard it. Wainwright \& Calnan (2002) suggested a strategy for coping as locating work stress in the responses of the individual and see the solution in terms of therapeutic intervention. They suggested physiological coping strategies against stress. The authors suggested the following: (1) biofeedback: electronic measurement of mind-body functions (muscle tension, intestinal activity, blood flow, breathing, heartbeat) and techniques to control those functions (2) muscle relaxation: self-regulated, progressive body relaxation that puts the individual in an extremely restful state. (3) aerobic activity: any type of activity that raises the level of one's pulse rate such as bicycling, swimming or jogging.

Montgomery and Rupp (2005) defined two main categories of coping strategies, active and passive coping strategies. Active coping strategies can be cognitive strategies (changes in perspective, imposing self-control, rational distancing of oneself); behavioural strategies (determining borderlines to the job, requesting advice from others, engaging in relaxation exercises); emotional strategies (remaining calm and quiet, thinking positively). On the other hand, passive coping strategies such as resignation, drinking, wishful thinking, and avoidance, are characterized by a lack of engagement with stressful event.

Hemmings and Hockley (2002) identified various strategies that can be used to cope with stress. These strategies include: communications with others; self-help; relaxation; organization; engaging in sports, etc. fun and entertainment also reduces stress and improves the quality and enjoyment of life, and there is a noticeable influence in self-care (regular exercise and sport, eight hours of sleep a day, preserving a correct diet, applying relaxation techniques) on the reduction of stress and improvement in the quality of life. As a result of the application or non-application of coping techniques, and sometimes as a direct result of stressful events, the individual experiences either positive emotions such as hope, pleasure, desire, enthusiasm, or negative emotions such as dread, frustration, disappointment, depression and even suicidal thinking. The individual can also experience feelings of satisfaction or dissatisfaction in work or in life in general, which could influence his/her commitment towards his/her job. Finally, such person may experience a feeling of exhaustion, depersonalization, or lack of fulfillment as aspects of burnout. It is therefore 
important for teachers to have personal coping strategies at their disposal for when stress inevitably occurs.

\section{Review of Related Literature}

Obi and Obi (2007) further saw stress as an aspect of the normal fabric of human existence. It is a fundamental part of the mastery of new skills and behavioural patterns. Okeke (2005) viewed stress as "the inability of a person to cope physically and psychologically with the demands of his environment. From these conceptualizations, stress can be regarded as the body's general response to any intense physical, emotional or mental demand, placed on the body system such that the individual is unable to content with. Where this situation exists in a chief executive in the discharge of his/her duties, it is known as administrative stress.

Stress in general and teachers' stress in particular is a complex and multifold phenomenon, which has diverse meaning. Generally, stress is an inability of a human being to cope with its surrounding environment (Dobson \& Smith, 2000). In fact, stress is the human's body response to the negative demands of environment. Whenever human beings encounter any environmental factor (stressor) which is a threat to his/her survivals then it experiences a feeling which is considered as stress. This stress comes from various aspects of life including developmental and social changes, financial and accommodation problems, work demands, and the specific demands of academia (Busari, 2011). Ogbonnaya (2009) explains that stress results when a teacher's working or living condition or circumstance makes demand beyond his capacity to handle physically or emotionally. It could be in form of disturbance in the system, strain, obstacles in the path of achieving goals, conflicting demands, uncertain role prescription such as ambiguity or role conflict and tasking work conditions.

Kyriacou and Chien (2004) investigated stress among elementary school teachers in Taiwan and found that stress among elementary school teachers constitutes a serious problem, since $26 \%$ of the teachers reported that they were under great to extreme stress. These findings correlate with the research of Kyriacou (2001) in which $20 \%$ to $30 \%$ of the teachers were reported to be suffering from stress. The main factors for stress were found to be the workload and the changes in educational reform that were conducted by the authorities. The extensive load and crowded conditions in the school and classes were an important factor for stress.

In the exploratory factor analysis carried out by Kokkinos (2007) in the research conducted among elementary school teachers in Cyprus, he defined eleven factors for stress: Pupil behavior, control over improper pupil behavior, decision making, connections with colleagues, ambiguity of role, poor working conditions, pupil respect for the teacher, workload, appreciation of teachers by their colleagues, time stress, certain teaching demands. The research conducted by Meng \& Liu (2008) found that the level of stress among teachers in China was extremely high, and that the stress factors among teachers in China were more serious than in other countries due to the educational system, the school environment, and the rigid value system. The prestigious status of mathematics in Chinese high schools increased the level of stress for teachers of Mathematics.

In their research, Meng \& Liu (2008) found that the five main causes of stress were pupils without motivation, pupils who showed a bad attitude towards class assignments; bad pupil behavior; a 
lack of teaching accessories, and of public understanding of the difficulties of the teaching profession. Less important causes were Special students in the class (e.g. with autism, attention deficit and hyperactivity disorder, low ability or low emotional intelligence), too many teaching subjects, overloaded tasks, and too few leisure hours, vocations and holidays. In an exploratory factor analysis (EFA) conducted for stress factors, they defined two main factors, the first of which they called the "teachers' work environment" and the second "teacher-pupil-parents relations". The research of Grayson and Alvarez (2008) found that bad relations with the administration, lack of public esteem, and improper behavior of the pupils increased the stress. Frequent changes, reforms and innovations in the education system, created stress, as well as poor working conditions, social and family problems (loneliness, divorce ...), and lack of social support led to high stress and reduction in the quality of life (Yang, Ge, Hu, Chi \& Wang, 2009).

A review of studies in past proves the moderating effects of teacher's resources on the stress and performance. Bradley (2007) found teacher's control as potential resources for buffering the effects of stress on the overall functioning of new start teachers in Australian schools. He found that teachers who had more control as psychological resource were having better performance as compared to others who did not (Bradley, 2007). Likewise teachers' control, the teacher's hardiness has also been found to have buffering effects on the stress in such way that teachers who have more psychological hardiness are in more better position to handle stress at work and they can perform well especially in tough times, when the job demands are high (Chan, 2003).

Haastrup and Adenike (2013) examined the various sources of stress among teachers of secondary schools in Ekiti State. They also examined the coping strategies of these teachers with stress. The descriptive research design of the survey type was used for the study. The population consisted of all the teachers in public secondary schools in the State. The sample was however made up of 180 teachers from 20 secondary schools across the three senatorial districts of the State. Stratified and simple random sampling techniques were used to select the sample. A self-designed instrument tagged 'Stress among teachers' Questionnaire (SATQ) which was validated by research experts in Tests and Measurement was used to collect data for the study. A test-retest method of reliability was used and a reliability coefficient of 0.79 was got using the Pearson product moment correlation. The data collected were analysed using percentage score and Pearson Product Moment Correlation. Among other findings, the study revealed a significant relationship between sources of stress and the teaching effectiveness of teachers.

The effects of teachers 'stress on the performance have widely been recognized. Research studies like (Bakker, Demerouti, \& Verbeke, 2004; Akhlaq, Amjad, Mehmood, Seed-ul-Hassan \& Malik, 2010; Tahir, 2011) shows that the stress has very negative effects in shape of low morale, absenteeism, poor teaching quality, less students satisfaction, and turn over on the overall performance of teachers. Under this process certain factors like resources, both personal as well as job resources buffer the negative effects of stress on the performance. Apart from control and hardiness, other teachers' resources (physical or psychological) like salaries, empowerment, autonomy, good physical conditions, self-efficacy, recognition etc, have also moderating effects on their job stress and performance. Betoret (2006) studied Spanish secondary school teachers and found that school physical resources and teachers self-efficacy had buffer the effects of stress on teachers, in such way that the teachers' performance increased with increase in resources (Betoret, 2006). 
The different stressors in shape of workload, role ambiguity, resource constraints, time shortage, job insecurity and worst job conditions, etc, exists within environment and act as hurdles for the teachers and thus hampering their performance (LePine, LePine \& Jackson, 2004). The resources (physical \& psychological) and personality of teachers act as buffer in changing the effects of stress on performance. The performance of teachers is supposed to increase in presence of resources and positive personality traits and vice versa. The resources act as instrumental and it boosts performance in such way that the teachers have the strength to handle the job demands and thus minimize the negative effects of stress on the performance (Arnold, Jari, Evangelia, \& Despoina, 2007). Consequently, stress coping strategies have often been encouraged.

Coping does not require success but only effort, and forms the link between environmental stress and adjustment of the individual. Teachers come into daily contact with pupils, confronting innumerable disruptions and difficulties with special need pupils, with the absence of sufficient resources and the lack of support - all those factors that had been shown above as causing stress. Their work does not end when they come home, and in order to withstand all this, a teacher has to adopt strategies of coping and adjustment. If the ability to cope is low or dependent only on basic and not well-developed coping strategies, this might lead to negative emotional reactions and burnout among teachers (Montgomery \& Rupp, 2005).

In the research conducted by Kyriacou and Chien (2004), they found that the best way to overcome stress was to adopt coping strategies such as "ensuring a healthy family life", besides "someone is standing by you and understands you". Other coping means are: "to ensure a good understanding of the material you have to teach"; "to learn how to control your emotions"; "to see the humor in the situation"; and "to rest after work". Regarding the means that the schools and authorities should take, according to the views of the teachers, the first place is given to "lessening the workload", followed by acquiring professional advice and raising salaries.

Bindhu and Sudheeshkumar (2006) found that there are two main categories to cope with stress: to give maximum attention to the stressful event, or not to think about it at all. In the research of Hemmings and Hockley (2002) various ways to cope with stress were found: Communications with others; self-help; relaxation; organization; engaging in sports, etc. fun and entertainment also reduces stress and improves the quality and enjoyment of life (McKay, 2008), and there is a noticeable influence in self-care (regular exercise and sport, eight hours of sleep a day, preserving a correct diet, applying relaxation techniques) on the reduction of stress and improvement in the quality of life (Yang et al., 2009). Teachers who find it difficult to cope with the behavior of pupils take various measures to disregard it, either by concealing the problem and pushing it away (not telling anyone about it), self-blame, worry and anxiety, development of eating and sleeping disorders, or even by becoming ill (Lewis, Romi, Qui \& Katz, 2005).

Montgomery and Rupp (2005) defined two main categories of coping strategies, active coping strategies and passive coping strategies. Active coping strategies can be cognitive strategies (changes in perspective, imposing self-control, rational distancing of oneself); behavioral strategies (determining borderlines to the job, requesting advice from others, engaging in relaxation exercises); emotional strategies (remaining calm and quiet, thinking positively). On the other hand, passive coping strategies such as resignation, drinking, wishful thinking, and avoidance, are characterized by a lack of engagement with the stressful event. 
Morgenstern (2000) however points out the delightful aspects of delegating responsibilities: "It allows for a very healthy interdependence among people. When you work as a team, it brings people together. Relationships solidify as you share the workload and learn to rely on one another". More important, a good deal of teacher stress often can be alleviated if only the teacher can learn to more effectively delegate job-related responsibilities. Very often the teachers' job is made a great deal less frantic if certain responsibility currently being handled by the teacher is dedicated to assistant teachers, teacher aides, volunteers and secretaries. The teacher has option to delegate to (1) experts, someone who can do it better, faster, more efficiently than he can, which makes instant time saving; (2) an equal, someone who is just as qualify as he does, and who can do it just as well as he can, with minimal time on his part to explain the job and give guidance (3) beginner, someone who doesn't know how to do it as well as the teacher but requires the teacher to invest some time to train and supervise him. Great rewards are accrued to this: The teacher becomes a mentor and a helper of someone to shine; this enhances his confidence in his abilities. As Morgensterns emphasizes, teachers should especially delegate the following kinds of jobs: (a) tasks they are not good at doing, and someone else can do better; (b) tasks they do not enjoy; (c) tasks that deplete them of energy or time needed for more important activities. Effective delegation of responsibilities could also enhance individual and school organization and coordination which can also minimize teacher-stress and burnout (Ogbonnaya, 2009)

The problem of stress management is not to eliminate stress completely but to learn how to cope with it. Stress currently provides one of the most challenging and most demanding health problems in modern medical practice (Obianyo, 2006). The role most teachers play today in secondary schools has recently gone beyond their job description. In most secondary schools, it is not uncommon to find one subject teacher for instance; an English language teacher to be the only teacher teaching all the classes from Junior School (JSS 1 - 3) to Senior Division (SSS 1 - 3). All of this workload on a teacher contributes to stress as little or on time is available to him/her to attend to other personal obligations in school or at home. Hence, this study is undertaken to investigate teacher stressors, effects and coping strategies among teachers in secondary schools in Esan Central Senatorial District, Edo State.

\section{Research Questions}

The following are the research questions raised to guide the study:

1) What are the sources of stress (stressors) among secondary school teachers in Esan Central Senatorial District, Edo State?

2) What are the effects of stress on secondary school teachers in Esan Central Senatorial District, Edo State?

3) What are the coping strategies used by secondary school teachers to manage stress in Esan Central Senatorial District, Edo State?

\section{Methods}

The descriptive survey design was adopted for this study. The population of the study covered all the six hundred and sixteen (616) public senior secondary school teachers in Esan Central Senatorial Edo State. The proportionate random sampling technique was used to select $50 \%$ of the teachers to make up a total of three hundred and eight (308) teachers for the study. The research instrument used for the collection of data was a 30 - item questionnaire titled Stress Assessment 
Questionnaire (SAQ) for teachers that was developed by the researcher from the reviewed literature. The questionnaire (SAQ for teachers) was divided into section A and B contain questions relating to the demographic characteristics of the respondent such as their sex while section B contained the items raised to elicit information's on the research questions.

The 30-items on the questionnaire bordered on causes (items 1-10), effects (items 11-20) and coping strategies for managing stressors (items 21-30). The instrument was based on a four point Likert scale: Strongly Agreed (A) -4, Agreed (A) -3, Disagreed (D) - 2 and Strongly Disagreed (SD) -1 . The dichotomous scale of 'Yes' and 'No' was not used to provide respondents with adequate options to rate their opinions on the item question. The content validity of this instrument was carried out by experts in Measurement and Evaluation, Ambrose Alli University Ekpoma, Edo State, Nigeria. The test-restest method was used to determine the reliability of the instrument. Descriptive statistics such as mean $(\overline{\mathrm{X}})$ and standard deviation (S.D) would be used to analyze the data collected. A mean score of 2.50 was used as the criterion mean such that any item was a mean score of 2.50 or higher was adjudged satisfactory while any items that is less than 2.50 was taken otherwise.

\section{Results}

The results from the analyses are presented below

Research Question 1: What are the sources of stress (stressors) among secondary school teachers in Esan Central Senatorial District, Edo State?

Table 1: Descriptive summary analysis on stressors among secondary school teachers in Edo

\begin{tabular}{|l|l|l|l|l|l|}
\hline S/N & Stressors & $\bar{X}$ & Std. Dev. & Remark & Mean ranking \\
\hline & $\begin{array}{l}\text { Work overload such as handling of } \\
\text { several subjects }\end{array}$ & $2.79^{*}$ & 1.02 & Agreed & $2^{\text {nd }}$ \\
\hline & Changes in educational reform & 2.10 & 1.06 & Disagreed & $7^{\text {th }}$ \\
\hline & Role ambiguity & 2.28 & 1.06 & Disagreed & $6^{\text {th }}$ \\
\hline & crowded class conditions & $2.61^{*}$ & 0.87 & Agreed & $5^{\text {th }}$ \\
\hline $\begin{array}{l}\text { poor working conditions such as low or } \\
\text { irregular salary }\end{array}$ & $2.74^{*}$ & 1.03 & Agreed & $3^{\text {rd }}$ \\
\hline & lack of social support & $2.88^{*}$ & 1.09 & Agreed & $1^{\text {st }}$ \\
\hline & lack of teaching accessories & $2.66^{*}$ & 0.76 & Agreed & $4^{\text {th }}$ \\
\hline & Other & 2.01 & 0.92 & Disagreed & $8^{\text {th }}$ \\
\hline
\end{tabular}

*Significant mean $(X \geq 2.50)$

Table 1 shows that majority of the students agreed on stressor 1, 4, 5, 6 and 7 at a mean score ranging from 2.61 to 2.88 while they disagreed on the items 2,3 and 8 at a mean score range of 2.01 to 2.28. Hence, result showed that work overload such as handling of several subjects, crowded class conditions, poor working conditions such as low or irregular salary, lack of social support and lack of teaching accessories were the major sources of stress (stressors) among secondary school teachers in Edo State. 
Research Question 2: What are the effects of stress on secondary school teachers in Esan Central Senatorial District, Edo State?

Table 2: Descriptive summary analysis on effects of stress on secondary school teachers in Esan Central Senatorial District, Edo State

\begin{tabular}{|l|l|l|l|l|l|}
\hline S/N & Effects & \multicolumn{1}{|c|}{$\overline{\mathrm{X}}$} & Std. Dev. & Remark & Mean ranking \\
\hline & Lowers teachers' morale & $2.80^{*}$ & 0.92 & Agreed & $3^{\text {rd }}$ \\
\hline & Encourages absenteeism & 2.18 & 1.17 & Disagreed & $7^{\text {th }}$ \\
\hline $\begin{array}{l}\text { lessens teachers' quality of } \\
\text { instructional delivery }\end{array}$ & $2.95^{*}$ & 1.10 & Agreed & $2^{\text {nd }}$ \\
\hline & lessens teachers' job satisfaction & $3.00^{*}$ & 1.09 & Agreed & $1^{\text {st }}$ \\
\hline & low job performance of teachers & $2.75^{*}$ & 1.14 & Agreed & $4^{\text {th }}$ \\
\hline & increases attrition among teachers & $2.69^{*}$ & 1.08 & Agreed & $5^{\text {th }}$ \\
\hline & increases fatigue among teachers & 2.21 & 0.68 & Disagreed & $6^{\text {th }}$ \\
\hline & others & 2.11 & 0.41 & Disagreed & $8^{\text {th }}$ \\
\hline
\end{tabular}

*Significant mean $(X \geq 2.50)$

Table 2 shows that majority of the students agreed on effect 1, 3, 4, 5 and 6 at a mean score ranging from 2.69 to 3.00 while they disagreed on item 2, 7 and 8 at a mean score range of 2.11 to 2.21 respectively. Hence, result showed that lowers teachers' morale, lessens teachers' quality of instructional delivery, lessens teachers' job satisfaction, low job performance of teachers and increases attrition among teachers were the major effects of stress among secondary school teachers in Edo State.

Research Question 3: What are the coping strategies used by secondary school teachers in Esan Central Senatorial District, Edo State?

Table 3: Descriptive summary analysis on coping strategies used by secondary school teachers in Esan Central Senatorial District, Edo State

\begin{tabular}{|l|l|l|l|l|l|}
\hline S/N & Coping Strategies & $\overline{\mathrm{X}}$ & Std. Dev. & Remark & Mean ranking \\
\hline & Getting emotional support from others & $2.61^{*}$ & 0.97 & Agreed & $3^{\text {rd }}$ \\
\hline & Seeing the situation in different manner & $2.56^{*}$ & 0.99 & Agreed & $4^{\text {th }}$ \\
\hline & Making fun with the situation & 2.18 & 0.88 & Disagreed & $7^{\text {th }}$ \\
\hline & Accepting responsibility to face the stress & $2.52^{*}$ & 0.95 & Agreed & $5^{\text {th }}$ \\
\hline $\begin{array}{l}\text { Finding comfort or solution through } \\
\text { prayers }\end{array}$ & $2.93^{*}$ & 0.85 & Agreed & $1^{\text {st }}$ \\
\hline & Self-criticism & 2.34 & 0.95 & Disagreed & $6^{\text {th }}$ \\
\hline & $\begin{array}{l}\text { Taking out some time to rest } \\
\text { Consumption of substances like } \\
\text { stimulants or pain killers }\end{array}$ & $2.66^{*}$ & 0.96 & Agreed & $2^{\text {nd }}$ \\
\hline
\end{tabular}

*Significant mean $(X \geq 2.50)$

Table 3 shows that majority of the student agrees on coping strategy 1,2, 4, 5 and 8 at a mean score ranging from 2.52 to 2.93 while the disagreed on item 3,6 and 7 at a mean score of 2.00 to 2.34 respectively. Hence, result showed that getting emotional support from others, seeing the situation in different manner, accepting responsibility to face the stress, finding comfort or solution 
through prayers and consumption of substances like stimulants or pain killers were the were the most employed coping strategies used by secondary school teachers to manage stress in Edo State.

\section{Discussions}

The result showed that work overload such as handling of several subjects, crowded class conditions, poor working conditions such as low or irregular salary, lack of social support and lack of teaching accessories were the major sources of stress (stressors) among secondary school teachers in Edo State. The result corroborates with that of Kyriacou and Chien (2004) that stress among elementary school teachers constitutes a serious problem, since $26 \%$ of the teachers reported that they were under great to extreme stress. Result agrees with that of Kyriacou (2001) that extensive load and crowded conditions in the school and classes were an important factor for stress. The result is in line with that of Meng and Liu (2008) that the level of stress among teachers in China were extremely high, and that the stress factors among teachers in China were more serious than in other countries due to the educational system, the school environment, and the rigid value system. The prestigious status of mathematics in Chinese high schools increased the level of stress for teachers of Mathematics.

Furthermore, result is in consonance with that of Meng and Liu found that the five main causes of stress were pupils without motivation, pupils who showed a bad attitude towards class assignments; bad pupil behavior; a lack of teaching accessories, and of public understanding of the difficulties of the teaching profession. The result is in line with that of Grayson and Alvarez (2008) who found that bad relations with the administration, lack of public esteem, and improper behavior of the pupils increased the stress. The result is also in aggrement with that of Yang, Ge, $\mathrm{Hu}$, Chi and Wang (2009) that frequent changes, reforms and innovations in the education system, created stress, as well as poor working conditions, social and family problems such as loneliness, divorce and lack of social support led to high stress and reduction in the quality of life among teachers.

The result showed that lowers morale, lessens teachers' quality of instructional delivery, lessens teachers' job satisfaction, low job performance of teachers and increases attrition among teachers were the major effects of stress among secondary school teachers in Edo State. Result corroborates that of Bradley (2007) that teachers who had more control as psychological resource were having better performance as compared to other teachers. Result is in agreement with that of Haastrup and Adenike (2013) that there was a significant relationship between sources of stress and the teaching effectiveness of teachers. Result is line with that of Bakker, Demerouti and Verbeke (2004) that the stress has very negative effects in shape of low morale, absenteeism, poor teaching quality, less students satisfaction, and turn over on the overall performance of teachers. Result is in consonance with that of Betoret (2006) found that school physical resources and teachers selfefficacy had buffer the effects of stress on teachers, in such way that the teachers' performance increased with increase in resources.

The result showed that getting emotional support from others, seeing the situation in different manner, accepting responsibility to face the stress, finding comfort or solution through prayers and consumption of substances like stimulants or pain killers were the were the most employed coping strategies used by secondary school teachers to manage stress in Edo State. Result corroborates 
that of Kyriacou and Chien (2004) that the best way to overcome stress was to adopt coping strategies such as "ensuring a healthy family life", besides "someone is standing by you and understands you". Other coping means are: "to ensure a good understanding of the material you have to teach"; "to learn how to control your emotions"; "to see the humor in the situation"; and "to rest after work". Regarding the means that the schools and authorities should take, according to the views of the teachers, the first place is given to "lessening the workload", followed by acquiring professional advice and raising salaries.

Result confirms that of Bindhu and Sudheeshkumar (2006) that there are two main categories to cope with stress: to give maximum attention to the stressful event, or not to think about it at all. Result is in line with that of Hemmings and Hockley (2002) that the following coping strategies were found significant communications with others; self-help; relaxation; organization; engaging in sports, etc. Result concurs with that of Morgenstern (2000) that coping strategies such as selfhelp and relaxation were mostly used by secondary school teachers.

\section{Conclusion}

Stress is one of the numerous challenges teachers face on a day to day basis at school. It is a cankerworm that emanates from work overload, crowded class conditions, poor working conditions, lack of social support and lack of teaching accessories among others. Based on findings, is it concluded that stress lessens teachers' quality of instructional delivery, lowers teachers' morale, job satisfaction, job performance and increases attrition among teachers.

\section{Recommendations}

The following recommendations are made on the study:

1) Teachers in Edo State should always endeavour to manage stress by getting emotional support from others such as more experience teachers who could give them directives on home to manage the current challenges they are facing at school.

2) Apart from seeing the positive situation in the stress situation and accepting responsibility to face it, teachers in Edo State should also explore other religious strategies such as finding comfort or solution through prayers in relation to their faith. This can help them find possible ways out of their stress situations that are confronted with at school.

\section{References}

[1] Akhlaq, M., Amjad, B. M., Mehmood, K., Hassan, S. \& Malik, S. (2010). An evaluation of the effects of stress on the job performance of secondary school teachers. Journal of Law and Psychology. ISSN: 2078-1083: 43-54.

[2] Arnold, H. Jari, D. Evangelia, C. \& Despoina, E. (2007). Job resources boost work engagement, particularly when job demands are high, Journal of Educational Psychology, 99(2), 274-284.

[3] Bakker, A. B. Demerouti, E. \& Verbeke, C. (2004). Using the job demands-resources model to predict burnout and performance, Human Resource Management, 43(1), 83-104.

[4] Betoret, F. D (2006). Stressor, self-efficacy, coping resources and burnout among secondary school teachers inn Spain. Educational Psychology: An International Journal of Experimental Educational Psychology, 4(26), 519- 539. 
[5] Betoret, F. (2006). Stressors, self-efficacy, coping resources and burnout among secondary school teachers in Spain, Educational Psychology, 26(4), 519-539.

[6] Bindhu, C. M, \& Sudheeshkumar, P. K (2006). Job Satisfaction and Stress Coping Skills of Primary School Teachers, Calicut: Department of Education publication, Kerala, India.

[7] Bradley, J. (2007). Job tenure as a moderator of stressor-strain relations: A comparison of experienced and new-start teachers. Work and stress. 21 (1), 46-48.

[8] Busari, A. O. (2011). Validation of student academic stress scale. European Journal of Social Sciences. 21(1): 94-105.

[9] Chien, P.Y. (2004). Teacher stress in Taiwanese primary school. Journal of Educational Enquiry, 5(2), 86-104

[10] Dobson E. \& Smith, H. (2000). What is stress and how does it affect reproduction? Animal Reproduction Science, 60(61), 743-752.

[11] Grayson, J. L, \& Alvarez, H. K. (2008). School Climate Factors Relating to Teacher Burnout: A Mediator Model. Teaching and Teacher Education. 24(5), 1349-1363.

[12] Hemmings, B. \& Hockley, T. (2002). Student teacher stress and coping mechanisms. Education in Rural Australia. 12(2) :25-35.

[13] Kokkinos, C. M. (2007). Job stressors, personality and burnout in primary school teachers. Br. $J$. Edu. Psychol. 77: 229-243.

[14] Kyriacou, (2001). Teacher stress: Directions for future research, Educational Review, 53(1), 27-35.

[15] Kyriacou, C. \& Chien, P. (2004). Teacher stress in Taiwanese primary schools. Journal of Educational Inquiry, 5(2): 86-104.

[16] LePine, J. A., LePine, C. D \& Jackson, O. A. (2004). Challenge and hindrance stress: Relationships with exhaustion, motivation to learn and learning performance, Journal of Applied Psychology, 89(5), 883-891.

[17] LePine, J. A. \& LePine \& Jackson, (2004). Challenge and hindrance stress: Relationship with exhaustion, motivation to learn and learning performance, Journal of Applied Psychology. 89(5), $883-891$

[18] Meng L, \& Liu S (2008). Mathematics teacher stress in Chinese secondary schools. Jounal Education English, 8(1), 73-96.

[19] Montgomery, C. \& Rupp, A. A (2005). A meta-analysis for exploring the diverse causes and effects of stress in teachers. Canadian Journal of Education 28(3), 458-486.

[20] Morgenstern, J. (2000). Time Management from the inside out. New York: Henry Holt and Company

[21] Obi, I. \& Obi, E. (2007). Stress Management. Awka: Sunrise Publications.

[22] Obianyo, N. E. A. (2006). Stress: A Global Health Concern. Enugu: Immaculate Publications Limited.

[23] Ogbonnaya, N. O. (2009). Social and political contexts of educational administration. Nsukka: Chuka Educational Publishers.

[24] Okeke, F. (2005). Stress and job satisfaction among secondary school principals in Imo State. Unpublished Ph.D Thesis. Abia State University.

[25] Tahir, F. (2011). Effectiveness of teaching stress on academic performance of college teachers in Pakistan, Effectiveness of Teaching Stress on Academic Performance of College Teachers in Pakistan, 1(3), 123-129.

[26] Wainwright, D. \& Calnan, M. (2002). Work stress: The making of a modern epidemic. Buckingham: Open University Press

[27] Yang, X., Ge, C., Hu, B., Chi, T., \& Wang, L. (2009). Relationship between quality of life and occupational stress among teachers. Public Health. 123(11):750-755. 